Acta Crystallographica Section E

Structure Reports

Online

ISSN 1600-5368

\section{Michael G. Gardiner,* \\ Roderick C. Jones, Celina M. Mason, Jason A. Smith and Lauren $E$. Wise}

School of Chemistry, University of Tasmania, Private Bag 75, Hobart, Tasmania 7001, Australia

Correspondence e-mail:

michael.gardiner@utas.edu.au

\section{Key indicators}

Single-crystal X-ray study $T=298 \mathrm{~K}$

Mean $\sigma(\mathrm{C}-\mathrm{C})=0.003 \AA$

$R$ factor $=0.044$

$w R$ factor $=0.125$

Data-to-parameter ratio $=12.7$

For details of how these key indicators were automatically derived from the article, see http://journals.iucr.org/e.

\title{
(RS)-2-(3,4-Methylenedioxyphenyl)-5-phenyl- 3,6-dihydro-2H-pyran
}

The title compound, $\mathrm{C}_{18} \mathrm{H}_{16} \mathrm{O}_{3}$, crystallizes with one molecule in the asymmetric unit. The conformation of the dihydropyran ring features puckering of the $\mathrm{O}$ atom by 0.612 (2) $\AA$ from the least-squares plane defined by the five $\mathrm{C}$ atoms [maximum deviation 0.1025 (12) §].

\section{Comment}

The cyclopropanation of chalcones has been widely reported and generates cyclopropyl ketones that have been used as synthetic intermediates and probes for reaction mechanisms (Murphy \& Wattanasin, 1981; Tanko \& Drumright, 1990). As part of an undergraduate laboratory project, such reactivity of (E)-3-(3,4-methylenedioxyphenyl)-1-phenylprop-2-eneone, (1) (Yang et al., 2006; Yathirajan et al., 2006), was examined using the sulfur ylide generated from trimethylsulfoxonium iodide (Corey \& Chaykovsky, 1965). However, if the reaction time was extended, a compound other than the cyclopropane, (2), was formed, as has been reported previously (Donnelly et al., 1974). The sulfur ylide is also effective in epoxidizing ketone functional groups and, while this competing reaction is slow compared with cyclopropanation, the initially formed cyclopropyl ketone can react further. This cyclopropyl epoxide, (3), is not stable, and passage through a plug of silica gel results in an acid-catalysed rearrangement to yield the title compound, (I). While (I) has been synthesized previously, only the melting point was reported (see Experimental). Here, we report its X-ray crystal structure.<smiles>O=C(/C=C/c1ccc2c(c1)OCO2)c1ccccc1</smiles>

(1)<smiles>O=C(c1ccccc1)C1CC1c1ccc2c(c1)OCO2</smiles><smiles>C1=C(c2ccccc2)COC(c2ccc3c(c2)OCO3)C1</smiles>

(I)
Received 15 December 2006 Accepted 19 January 2007

The molecular structure of (I) is depicted in Fig. 1, confirming the cyclization-based rearrangement of (3) upon 


\section{organic papers}

reaction work-up following cyclopropanation of the alkene and epoxidation of the ketone. Selected geometric parameters, describing the ring conformations and the planarity of the non-cyclic conjugated functionalities, are listed in Table 1.

Compound (I) represents the first structurally characterized 2,5-diaryl-substituted 3,6-dihydropyran. The heterocyclic ring conformation features the $\mathrm{O}$ atom displaced by 0.612 (2) $\AA$ from the otherwise essentially coplanar atoms of the sixmembered ring [maximum deviation of 0.1025 (12) $\AA$ for atom $\mathrm{C} 4$ from the least-squares plane defined by the five $\mathrm{C}$ atoms] and is unique amongst the known solely 2,5-disubstituted derivatives. These examples have universally featured saturated $\mathrm{C}$ atoms directly bound to the 5-position and a variety of $\mathrm{Csp}{ }^{2}$-based substituents in the 2-position. Their conformations appear to favour puckering of the $\mathrm{C}$ atom in the 2-position and, to a lesser extent, the $\mathrm{O}$ atom on opposite sides of the ring (Puliti et al., 1990; De Rosa et al., 1995; Cheung \& Snapper, 2002; Cheung et al., 2004), except for the case of one example where these same two atoms are substantially displaced on the same side of the ring, owing to the macrocyclic ring constraints of the substituents (Alvarez \& Delgado, 1988).

\section{Experimental}

The synthesis of (I) was carried out as follows. Dimethyl sulfoxide $(10 \mathrm{ml})$ was added dropwise to a mixture of sodium hydride $(390 \mathrm{mg}$ of $60 \%$ in mineral oil) and trimethylsulfoxonium iodide (2.0 g) under an atmosphere of nitrogen and stirred at $298 \mathrm{~K}$ for $20 \mathrm{~min}$. The mixture was cooled to $283 \mathrm{~K}$, compound (1) (1.0 g, $4.0 \mathrm{mmol}$; Ranu \& Jana, 2005) was added in small portions over a period of $5 \mathrm{~min}$, and then the mixture was heated at $323 \mathrm{~K}$ for $2 \mathrm{~h}$ before stirring overnight at $298 \mathrm{~K}$. The mixture was poured into an ice-water slurry $(100 \mathrm{ml})$ and extracted with ethyl acetate $(3 \times 20 \mathrm{ml})$, and the combined organic extracts were dried and evaporated to give an oil. The oily material was passed through a small plug of silica gel, eluted with $10 \%$ ethyl acetate/petroleum spirits. A solid precipitated from the eluent, and this was collected and recrystallized from ethyl acetate to yield the pyran, (I), as colourless crystals suitable for X-ray analysis [yield 60\%; m.p. 425-427 K; literature value 430-431 K (Donnelly et al., 1974)]. Spectroscopic data are available in the archived CIF.

Crystal data
$\mathrm{C}_{18} \mathrm{H}_{16} \mathrm{O}_{3}$
$M_{r}=280.31$
Triclinic, $P \overline{1}$
$a=6.6380(13) \AA$
$b=7.911(10) \AA$
$c=13.498(5) \AA$
$\alpha=81.24(5)^{\circ}$
$\beta=80.21(2)^{\circ}$
$\gamma=82.05(4)^{\circ}$

$$
\begin{aligned}
& V=685.7(9) \AA^{3} \\
& Z=2 \\
& D_{x}=1.358 \mathrm{Mg} \mathrm{m}^{-3} \\
& \text { Mo } K \alpha \text { radiation } \\
& \mu=0.09 \mathrm{~mm}^{-1} \\
& T=298(2) \mathrm{K} \\
& \text { Plate, colourless } \\
& 0.55 \times 0.45 \times 0.10 \mathrm{~mm}
\end{aligned}
$$

\section{Data collection}

Enraf-Nonius TURBOCAD-4
diffractometer $\omega / 2 \theta$ scans

Absorption correction: none 2750 measured reflections 2413 independent reflections

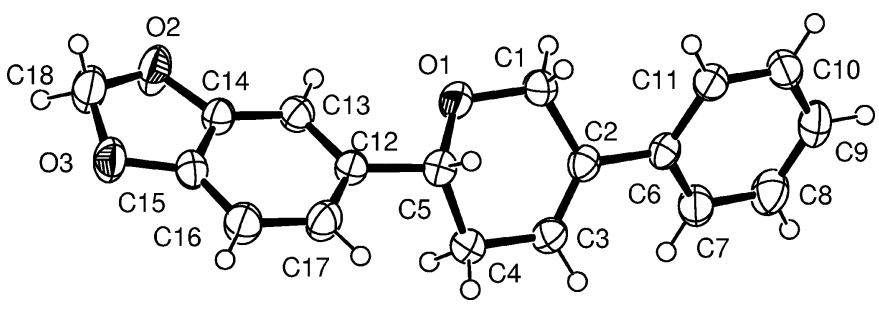

Figure 1

The molecular structure of (I), showing the atom-labelling scheme. Displacement ellipsoids are drawn at the $50 \%$ probability level and $\mathrm{H}$ atoms are represented by circles of arbitrary size.

\section{Refinement}

Refinement on $F^{2}$

$R\left[F^{2}>2 \sigma\left(F^{2}\right)\right]=0.044$

$w R\left(F^{2}\right)=0.125$

$S=1.06$

2413 reflections

190 parameters

$\mathrm{H}$-atom parameters constrained

$$
\begin{gathered}
w=1 /\left[\sigma^{2}\left(F_{\mathrm{o}}{ }^{2}\right)+(0.0716 P)^{2}\right. \\
+0.1555 P] \\
\text { where } P=\left(F_{\mathrm{o}}{ }^{2}+2 F_{\mathrm{c}}{ }^{2}\right) / 3 \\
(\Delta / \sigma)_{\max }<0.001 \\
\Delta \rho_{\max }=0.24 \mathrm{e}^{-3} \\
\Delta \rho_{\min }=-0.19 \mathrm{e}^{-3}
\end{gathered}
$$

\section{Table 1}

Selected geometric parameters $\left(\AA{ }^{\circ}\right)$.

\begin{tabular}{lrlr}
\hline $\mathrm{O} 1-\mathrm{C} 5$ & $1.416(2)$ & $\mathrm{C} 2-\mathrm{C} 6$ & $1.477(2)$ \\
$\mathrm{O} 1-\mathrm{C} 1$ & $1.418(2)$ & $\mathrm{C} 3-\mathrm{C} 4$ & $1.496(2)$ \\
$\mathrm{C} 1-\mathrm{C} 2$ & $1.508(2)$ & $\mathrm{C} 4-\mathrm{C} 5$ & $1.525(2)$ \\
$\mathrm{C} 2-\mathrm{C} 3$ & $1.327(2)$ & & \\
$\mathrm{C} 5-\mathrm{O} 1-\mathrm{C} 1$ & $111.78(14)$ & $\mathrm{C} 2-\mathrm{C} 3-\mathrm{C} 4$ & $123.14(16)$ \\
$\mathrm{O} 1-\mathrm{C} 1-\mathrm{C} 2$ & $113.01(14)$ & $\mathrm{C} 3-\mathrm{C} 4-\mathrm{C} 5$ & $110.94(14)$ \\
$\mathrm{C} 3-\mathrm{C} 2-\mathrm{C} 6$ & $124.15(15)$ & $\mathrm{O} 1-\mathrm{C} 5-\mathrm{C} 12$ & $108.62(14)$ \\
$\mathrm{C} 3-\mathrm{C} 2-\mathrm{C} 1$ & $119.37(15)$ & $\mathrm{O} 1-\mathrm{C} 5-\mathrm{C} 4$ & $110.16(14)$ \\
$\mathrm{C} 6-\mathrm{C} 2-\mathrm{C} 1$ & $116.48(14)$ & $\mathrm{C} 12-\mathrm{C} 5-\mathrm{C} 4$ & $113.69(14)$ \\
& & & \\
$\mathrm{C} 5-\mathrm{O} 1-\mathrm{C} 1-\mathrm{C} 2$ & $52.1(2)$ & $\mathrm{C} 1-\mathrm{O} 1-\mathrm{C} 5-\mathrm{C} 4$ & $-65.77(19)$ \\
$\mathrm{O} 1-\mathrm{C} 1-\mathrm{C} 2-\mathrm{C} 3$ & $-18.6(2)$ & $\mathrm{C} 3-\mathrm{C} 4-\mathrm{C} 5-\mathrm{O} 1$ & $44.0(2)$ \\
$\mathrm{C} 1-\mathrm{C} 2-\mathrm{C} 3-\mathrm{C} 4$ & $-0.1(3)$ & $\mathrm{C} 3-\mathrm{C} 2-\mathrm{C} 6-\mathrm{C} 7$ & $27.5(3)$ \\
$\mathrm{C} 2-\mathrm{C} 3-\mathrm{C} 4-\mathrm{C} 5$ & $-12.5(2)$ & $\mathrm{C} 3-\mathrm{C} 2-\mathrm{C} 6-\mathrm{C} 11$ & $-155.07(17)$ \\
\hline
\end{tabular}

All $\mathrm{H}$ atoms were placed in calculated positions and refined using a riding model, with $\mathrm{C}-\mathrm{H}$ distances constrained to 0.93 (aromatic $\mathrm{CH}$ ), $0.97\left(\right.$ methylene $\left.\mathrm{CH}_{2}\right)$ or $0.98 \AA$ (methine $\left.\mathrm{CH}\right)$, and with $U_{\text {iso }}(\mathrm{H})=$ $1.2 U_{\text {eq }}$ (carrier C).

Data collection: CAD-4 EXPRESS (Enraf-Nonius, 1994); cell refinement: CAD-4 EXPRESS; data reduction: XCAD4 (Harms \& Wocadlo, 1995); program(s) used to solve structure: SHELXS97 (Sheldrick, 1997); program(s) used to refine structure: SHELXL97 (Sheldrick, 1997); molecular graphics: $X$-SEED (Barbour, 2001) and ORTEP-3 (Farrugia, 1997); software used to prepare material for publication: Win GX (Farrugia, 1999).

The authors acknowledge the support of the School of Chemistry for funding this project.

\section{References}

Alvarez, L. \& Delgado, G. (1988). J. Org. Chem. 53, 5527-5530.

Barbour, L. J. (2001). J. Supramol. Chem. 1, 189-191.

Cheung, A. K., Murelli, R. \& Snapper, M. L. (2004). J. Org. Chem. 69, 5712 5719.

Cheung, A. K. \& Snapper, M. L. (2002). J. Am. Chem. Soc. 124, 11584-11585. Corey, E. J. \& Chaykovsky, M. (1965). J. Am. Chem. Soc. 87, 1353-1364.

De Rosa, S., Puliti, R., Crispino, A., De Giulio, A., De Sena, C., Iodice, C. \& Mattia, C. A. (1995). Tetrahedron, 51, 10731-10736. 


\section{organic papers}

Donnelly, J. A., O’Brien, S. \& O’Grady, J. (1974). J. Chem. Soc. Perkin Trans. 1, pp. 1674-1676.

Enraf-Nonius (1994). CAD-4 EXPRESS. Enraf-Nonius, Delft, The Netherlands.

Farrugia, L. J. (1997). J. Appl. Cryst. 30, 565

Farrugia, L. J. (1999). J. Appl. Cryst. 32, 837-838.

Harms, K. \& Wocadlo, S. (1995). XCAD4. University of Marburg, Germany.

Murphy, W. S. \& Wattanasin, S. (1981). J. Chem. Soc. Perkin Trans. 1, pp. 2920

2926.
Puliti, R., De Rosa, S., Mattia, C. A. \& Mazzarella, L. (1990). Acta Cryst. C46, 1533-1536.

Ranu, B. C. \& Jana, R. (2005). J. Org. Chem. 70, 8621-8624.

Sheldrick, G. M. (1997). SHELXS97 and SHELXL97. University of Göttingen, Germany.

Tanko, J. M. \& Drumright, R. E. (1990). J. Am. Chem. Soc. 112, 5362-5363.

Yang, X.-H., Wu, M.-H., Zou, W.-D. \& Li, C. (2006). Acta Cryst. E62, o3117o3118.

Yathirajan, H. S., Sarojini, B. K., Narayana, B., Bindya, S. \& Bolte, M. (2006) Acta Cryst. E62, o3629-03630. 